Case Reports

\title{
Traditional Fishermen in Rote Island: An Alternative Livelihood to Illegal Fishing Activities in the Indonesian- Australian Transboundary Waters
}

\author{
${ }^{1}$ Fred Benu, ${ }^{2}$ Paul G. King, ${ }^{3}$ AgusNalle and ${ }^{4}$ Moni Muskanan \\ ${ }^{1,3,4}$ Nusa Cendana University, Jl. Adisucipto, \\ Penfui, Kupang 85001, East Nusa Tenggara Province, Indonesia \\ ${ }^{2}$ Centre of Excellence Sustainable Development Indonesia (CESDI), \\ School of Environment, Griffith University, Australia
}

Article history

Received: 31-05-2018

Revised: 02-06-2018

Accepted: 24-07-2018

Corresponding Author:

Fred Benu,

Nusa Cendana University, Jl.

Adisucipto, Penfui, Kupang

85001, East Nusa Tenggara

Province, Indonesia

Tel: +628123798246

Email: benufred@yahoo.com

\begin{abstract}
At the moment there are about 210 Indonesian fishermen, many from Rote Island, the majority from the village of Papela, still detained in Australia Detention Centres for carrying on illegal fishing activities in the Australian Exclusive Economic Zone. These fishing activities are not driven by economic factors only, but also by their historical background. By understanding the economic, historical and socio-cultural background of the fishermen, a comprehensive solution for illegal fishing might be established. This research aims to ascertain an alternative economic activity for the fishermen that can give increased job opportunities for the fishermen to attain a sustainable livelihood as part of sustainable economic development. This research has used qualitative and quantitative analysis techniques including stakeholder interviews, descriptive researcher observations, a household survey and Policy Analysis Matrix (PAM). The results of the research show that; (i) since the beginning of the 17th century, the traditional fishermen of Papela have made regular offshore fishing trips to waters that are now within the Australian Exclusive Economic Zone; (ii) based on socio-cultural assessment and economic calculations, a salt pond business is an efficient business with comparative advantages for the Papela fishermen as an alternative source of income; and (iii) even though, a salt pond business has economic potential and has already been conducted by a small number of people in Papela, the government's will to support the salt farmer seems weak.
\end{abstract}

Keywords: Illegal Fishing, Socio-Cultural Values, Historical Background, Economic Development, Alternative Livelihood, Policy Analysis Matrix, Sustainable Development

\section{Introduction}

There have been many studies conducted on livelihood strategies in marginalised fishing villages. Most of these studies were conducted in developing countries and were driven by the fact that most fishermen are living in poverty in villages located in rural, remote areas, with very few alternative employment opportunities (Allison and Ellis, 2001; Allison and Horemans, 2006; Anderson and Obeng, 2017; Béné, 2006; Christy Jr., 1986; Knudsen, 2016; Weeratunge et al., 2015; Purcell and Pomeroy, 2015).
Fishermen have been labelled as "the poorest of the poor" (Bene, 2003). Bene reviewed the perceptions embraced by academics, international agencies and practitioners about the relationship between fisheries and poverty in developing countries. He identified two perspectives with which to perceive poverty in fisheries, which are "They are poor because they are fishermen" and "they are fishermen because they are poor". These statements describe the poverty in fisheries in the sense that whatever they try to do, they will remain poor and being a fisherman is an economic activity of last resort for the poor (Allison and Horemans, 2006; Béné, 2006). 
A number of authors explain that the fishery activities in those areas are identified as Small-Scale Fisheries (SSF) carrying on artisanal fishing activities. They are always depicted as having very low income levels and causing the over-exploitation of the environment and biological resources (Allison and Ellis, 2001; Allison and Horemans, 2006; Bene, 2009; Knudsen, 2016; Weeratunge et al., 2015) However, the fishers still maintain their subsistence living activities while ignoring future sustainability because of the lack of alternative skills and readily available alternative income sources (Knudsen, 2016).

Hence, to propose a solution to alleviate poverty in fishing villages requires a broad and comprehensive approach to understanding the cause and nature of poverty in the fisheries' context. It cannot be simplified only to the level of income and consumption and/or environmental (resource scarcity) dimensions. This does not deny the fact that fisher folks' resource dependence and the open-access nature of fisheries, together, lead to resource degradation and impoverished fishing communities (Allison and Ellis, 2001; Allison and Horemans, 2006). The fishers' reasons for continuing to fish in over-exploited waters are more complicated than economic factors only (Knudsen, 2016). It is also necessary to have a comprehensive understanding of the socio-cultural and institutional dimension of poverty in fisheries for better interpretation of the internal factors deriving from the fishermen's socio-economic background and the external factors (policies, institutions and organizations) that influence the fishers access to resources and livelihood activities to cope with various forms of stress and shocks (Allison and Horemans, 2006).

This research dealt with the issue of the socioeconomic and cultural background of the traditional fishermen of Rote Island (Fig. 1) that has influenced the practice of illegal fishing in the trans-boundary waters between Indonesia and Australia. By understanding the economic, historical and sociocultural background of the local traditional fishermen in Papela, alternative livelihood strategies can be proffered to help curtail fishing activities that become, illegal resulting in detention, when these fishermen stray into Australian waters.

The specific aims of the research are, (i) to identify and explain some of socio-cultural factors determining the local people's livelihoods; (ii) based on the sociocultural assessment and economic calculations, suggest an alternative livelihood with comparative advantages for the Papela fishermen as a source of complementary income using their existing skills; and (iii) to analyse government policy for enhancing alternative livelihoods for the local people.

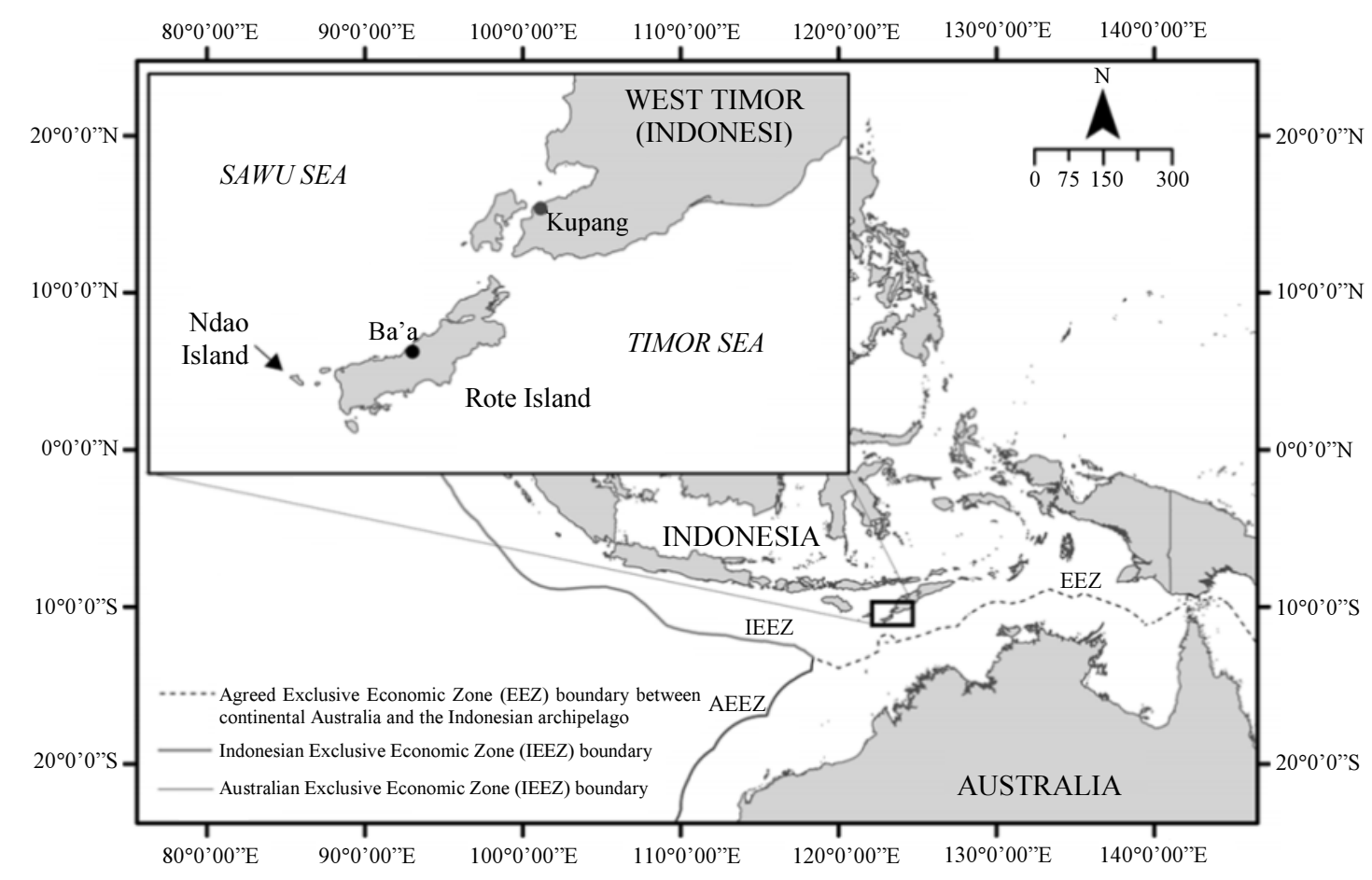

Fig. 1: Map of rote-ndao district in East Nusa Tenggara Province, Indonesia 


\section{Contextualising the Research}

\section{History of Rotenese Traditional Fishermen}

The District of Rote Ndao is one of the 92 outer islands of Indonesia, located near the trans-boundary waters of neighbouring countries, including Australia and Timor Leste. Rote Ndao has $2000 \mathrm{Km}^{2}$ of land and $570 \mathrm{~km}$ of coastline. Historically, according to Ardani (2017), one of the traditional narrators of Papela, the story of offshore fishing activities to Ashmore Reef commenced in 1680 by AmaRohi. At that time, Captain Rohi together with his crew were fishing in and around the Timor Sea, but because of bad weather conditions and a sudden storm, they were carried further out to sea and accidently discovered a cluster of sand islands in the south of the Timor Sea. The year of 1680 is calculated based on the story that in 1817 some fishermen from Solor, East Flores, arrived in Papela. They related a story told by the fifth generation of Captain Rohi about their ancestor's voyage to Ashmore Reef.

The first island Captain Rohi and his crew arrived on was devoid of fresh water, so they only had coconuts to drink. Captain Rohi and his crew dug a well to find fresh water, but having only found brackish water; they moved to a second island and dug another well, this time finding drinkable water. Since that time,
Rotenese fishermen, especially fishermen from Papela, have made regular offshore fishing voyages to Ashmore Reef (Sand Island/Pulau Pasir), which is now inside the Australian EEZ (Fig. 2).

The history of regular offshore fishing voyages to Sand Island since the beginning of 17th century is attested by the Agreement between the Indonesian and Australian Governments signed first in 1974 (Memorandum of Understanding Between the Government of Australia and the Government of the Republic of Indonesia Regarding the Operations of Indonesian Traditional Fisheries in Areas of the Australian Exclusive Fishing Zone and Continental Shelf, 1974). Hence, the rights of traditional fishermen from Rote, to go fishing in the trans-boundary waters, have been affirmed by both Governments. However, both countries still have a problem with the definition of "traditional", which defines who should be categorized as "traditional fishermen". The definition of traditional fishermen is important because those who are considered traditional have the right to collect the resources near the five tiny islands found in the $\mathrm{MoU}$ Box to the northwest of Australia. The definition of traditional used gives sense to the notion of 'tradition' by specifying not just methods and type of vessels used, but also by the historical continuity of such fishing activities (Campbell and Wilson, 1993).

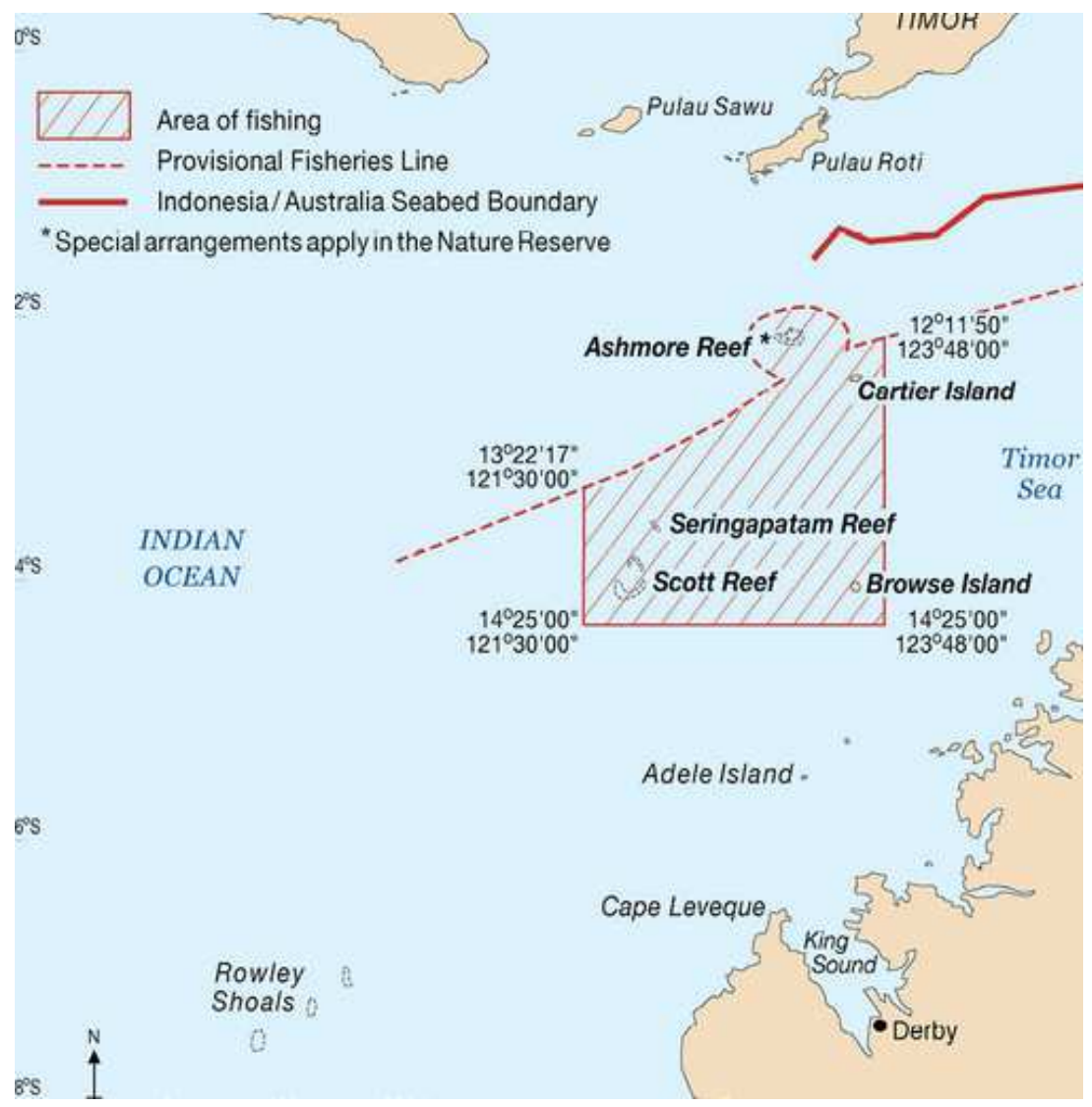

Fig. 2: An area in the Australian Exclusive Economic Zone known as MoU Box (Fox and Sen, 2002) 
However, since the maritime boundaries were changed, fishing activities by Indonesian fishers are considered illegal by Australian authorities when nontraditional fishermen enter any part of the Australian EEZ or when traditional fishermen using traditional boats and equipment stray out of the MoU Box, as defined in a 1989 Practical Guidelines for Implementing the $1974 \mathrm{MoU}$ between Australia and Indonesia (Fig. 2). The agreement, in accordance with the historical narrative, does state that Indonesian traditional fishermen are still allowed to moor at two other small islands to replenish their fresh water supplies; East Islet $\left(12^{0} 15^{\prime} S L-123^{0} 07^{\prime} E L\right)$ and Middle Island $\left(12^{0} 15^{\prime} S L-123^{0} 03^{\prime} E L\right)$ (AMMBOIAF, 1989).

A recent media report stated that there are at least 200 cases of illegal fishing per year conducted by traditional fishermen from Rote Island, mainly from Papela in East Rote and that currently there are about 210 Indonesian fishermen detained in Australia Detention Centres (Victory News, 2017). These traditional fishermen carry on their fishing activities not only in Indonesian waters, but also in the MoU Boxin Australian waters, which encompasses Ashmore Reef, or Pulau Pasir (Sand Island) as it is known by the Indonesian fishermen and a number of other reefs and atolls. These fishing practices are not driven merely by economic factors, but also by their socio-historical background (Balint, 2005).

\section{History of Poverty in Papela}

Since the 1970s, many studies have been conducted in Roti Island, especially related to illegal fishing in the trans-boundary waters between Australia and Indonesia. Most of the studies are related to Rotenese fishermen who access the MoU Box and focuson different perspectives including: social-culture, law, economy, public administration, anthropology, among others (Adhuri, 2012; Fox and Sen, 2002; Stacey, 2007).

According to Carnegie (2010) and Fox (1977), Rote Island is in a relatively isolated geographic location. Nevertheless, Rote Island has a complex history which blends elements of local customs and ongoing interaction with people from outside through trade and cultural exchanges that have influenced their livelihood strategies. Historically, according to Barlow and Gonowarsito (2007) and as Fox (1977) put it: "Rote's maritime context has ensured continued contact with other peoples, particularly through religious missions, commerce and colonization".

Traditionally, Rotenese livelihoods and social hierarchies have been organized around the harvest of the lontar palm (Borassus flabellifer). Their livelihoods have also relied on subsistence agricultural and fishing activities. A case study conducted by Pellu (2008) in LanduLeko, East Rote, found that over the past few decades, the majority of people in the villages have stopped their palm tapping activities. The reason behind this change is the reduction of time allocated to tapping activities because of additional time allocated to activities in rice fields, tending seaweed farms and occasionally going off-shore to fish. In 2001, a seaweed farming industry was initiated by the Australian Agency for International Development (AusAID), as a means of additional income and economic survival (Barlow and Gonowarsito, 2007; Carnegie, 2008).

Papela, situated in the eastern part of Rote Island, is one of the most frequent objects of empirical studies, as the majority of households are traditional fishers and many of them are involved in illegal fishing activities to gain a household income. There are various determinants of livelihood strategies driving Rotenese fishers, but in Papela their socio-culture background has a strong influence shaping their fishing livelihood activities (Adhuri, 2012; Fox and Sen, 2002). The studies about Papela reveal that more than $80 \%$ of household heads identify their occupation as full-time fishers (Fox, 2002). Papela is the organizational centre for crew recruitment for voyages to the MoU Box in the Australian EEZ; it is also the initial marketing centre for the marine products obtained on these voyages (Fox and Sen, 2002; Sembiring et al., 2012).

Most Papela fishermen originate from Makassar in South Sulawesi, Alor, another island in East Nusa Tenggara, or are Bajo people from Southeast Sulawesi. Their ancestors came to Rote during their voyages south to the fish-rich waters where Indonesian sea water flows from the Pacific Ocean to the Indian Ocean (Gordon, 2005, cited by Benu et al., 2017a). They have been fishing in the region since 1720 (MacKnight, 1976; 1986), or maybe even earlier, since 1640, according to Ganter (2008). They originally focused on gathering sea cucumber (trepang, edible Holothuroidea) for trade with the Chinese (Clark and May, 2013). However, according to Prescott et al. (2015), recent fishing activities also targeted fish from several commercial species, namely Indian Mackerel (Rastrelliger spp.), Herring (Herklotsichthys spp.), Sardines (Sardinella spp.) and small Tuna of the family Scombridae (e.g., Auxis thazard). Although in some years significant catches also include Squid (Uroteuthis bartschi) and other less common species. Marine Turtles are also taken for consumption or sale if caught as by catch.

In his survey, Fox (2002) found that education levels in Papela are much lower than in the rest of the island of Rote, noting the existence of a local primary school (SD Negeri) with only eight full-time teachers. Fox (2002) found that $52 \%$ of the population had completed primary school, while none of the Bajo fishermen who live at Tanjung Pasir, a rudimentary sub-village of Papela located on a small sand spit adjacent to the main village, had completed primary school and most were reported to be illiterate. An additional $27 \%$ of the Papela population had completed junior high school and a further $16 \%$ had completed senior high school. No one was reported to have had any education beyond high school. Children as young as twelve are taken on fishing voyages to be educated on the ways of the sea and their socio-cultural heritage. Local government statistics confirm this 
pattern (BPS Kabupaten Rote-Ndao, 2017), that Londalusi, of which Papela forms a significant part, still has the lowest school attendance in East Rote. Only $85 \%$ of school age children (7-12 years) attend primary school compared to rates of over 90 to $100 \%$ for other districts.

Fox and Sen (2002) stated that seasonal factors affect employment patterns. During the west monsoon from January to April, winds and waves limit fishing. Only the Bajo in Papela are reported to fish regularly during this season. However, $93 \%$ of the population is involved in fishing during the east monsoon from May to June and again from September to December. July and August are a time of strong winds and most fishermen curtail fishing during this period. Alternative income sources vary for households in Papela, especially during the monsoon season. They included local trading, particularly of dried fish, day labour for local construction, boat building and repair, sea grass farming and small kiosks, selling daily needs, run from the front of their houses. There are few horticulture activities because of landless, which is common for most fishing households. Thus, rice and other basic food stuffs must be purchased locally or obtained by trading fish. When in need, households borrow from wealthy local perahu (boat) owners, for whom they work and to whom they may wellbe related, or alternatively borrow from local traders. Most Papela families are bound by bonds of dependence based on kinship and debt (Fox et al., 2009; Sembiring et al., 2012; Therik, 2008).

Overall, most of the previous studies tend to specifically assess how the changes in maritime boundaries (1974 MoU, the 1983 declaration of the Ashmore Reef Nature Reserve and the 1989 Review of the $1974 \mathrm{MoU}$ to include a MoU Box (Forbes, 1995)) deprive the fishers of a livelihood and describe their poverty and subsistence living conditions (Balint, 2005; Stacey, 2007). This paper actually adds to the previous studies by assessing the poverty and the local context, then proposes livelihood strategies to improve poverty alleviation efforts in Papela.

\section{Sustainable Economic Development}

As stated in Section 1.1, the definition of poverty in fishing villages has evolved from basic measurements of income and consumption, the predominant criteria in development economics in the 1960s. Analysis now includes a comprehensive measurement of basic needs and basic human rights, including the psychological aspects such as the feelings of powerlessness, humiliation and insecurity (Allison and Horemans, 2006; Béné, 2006). There is new recognition that poverty is not just a failure to meet minimum nutrition or subsistence levels of income, but also includes the deprivation of the materials and rights required to meet minimally acceptable human needs such as health and education, clean water and sanitation services and resource access required to sustain livelihoods (Allison and Ellis, 2001; Allison and Horemans, 2006). Alleviating poverty means developing access to the minimally acceptable human needs, while still maintaining the environment in a sustainable livelihood system. This process is called Sustainable Development (SD) (Hopwood et al., 2005; Horner, 2013).

Hopwood et al. (2005) describe how SD has evolved from status quo, reformation and transformation stages. Status quo proposes development but sees neither the environment nor society as overwhelming issues while a reformation approach critically acknowledges current policies of most businesses and governments and trends within society, but ignores a collapse in ecological or social systems in the development process. The current comprehensive approach of SD is transformation, which recognizes the environment and society as fundamental features of sustainable development and it acknowledges the significant links between human activities and the environment (Horner, 2013).

In the context of Sustainable Economic Development (SED) in tandem with Sustainable Livelihoods (SL), humans have a right of freedom to Economic Development (ED), called expansion of freedoms, which is not merely freedom of economic activities (the freedom to enter into market exchanges) or political activities (the freedom to vote and be an active citizen), but humans also have rights to consider true freedom to access social services such as health care, sanitation, nutrition and education (Sen, 1999; cited in Miletzki and Broten, 2017). At the same time, humans have the responsibility to maintain the environment to sustain a livelihood system. SD has a strong commitment to social equity, with a view that access to livelihood, good health, resources and economic and political decision making are all connected. In the absence of people having control over their lives and resources, inequality and environmental degradation are inevitable (Hopwood et al., 2005; Horner, 2013; Meier, 1976). To maintain social equity, strong commitment from the stakeholders to maintain the environment based on their responsibilities is needed (Meier, 1976). Consequently, it can be seen that there is a strong relationship between poverty, SL and ED and SD, in which reducing poverty by applying a SL approach is one of most important indicators to achieving SED (Allison and Ellis, 2001; Bene, 2009; Béné, 2006; Knudsen, 2016).

Put in other words, it is necessary to approach poverty alleviation with a SL perspective to attain SED. The assessment of poor fishermen in most empirical studies is multi-dimensional in nature (Knudsen, 2016) and is characterized by overcrowded living conditions with inadequate services, low levels of education and a lack of skills and assets (particularly land), living in remote and isolated communities, poorly organised, politically voiceless and often highly exposed to accidents and natural disasters (Allison and Horemans, 
2006). This indicates that, in general, fishers have not been endowed with their rights of freedom (Miletzki and Broten, 2017) as measured by four discrimination indicators in poverty assessment; social marginalization, economic exclusion, class exploitation and political disempowerment in the livelihood system (Béné, 2006).

\section{Methods}

\section{Sustainable Livelihoods}

To assess the current living conditions of the fishermen in Papela and propose a multi-dimensional solution, this paper operationalizes a Sustainable Livelihood Approach (SLA) and its main principles (Allison and Horemans, 2006; Scoones, 1998). Figure 3 demonstrates the process that a SLA proposes to assess the level of local livelihood assets, i.e. Human, Natural, Financial, Physical and Social Capital, along with the policies, institutions and processes that the fishers have access to, to enable sustainable livelihood strategies and outcomes that in the long run will support the fishers to cope with stresses, shocks, trends and seasonality (Allison and Ellis, 2001; Allison and Horemans, 2006; Bebbington, 1999; Carney, 1998; Reardon and Vosti, 1995; Sherbinan et al., 2007).

Capital assets need to be further divided into asset groups that are owned, controlled, claimed, or by some other means available for the fishers' sustainable livelihood pursuits. They are grouped into five categories: Physical Capitalis separated into household level (boats, fishing gear, houses, cars, bikes and bicycle) and community level (access to infrastructure such as harbours, road networks, clinics and schools). Financial Capital is control and access to savings, credit and insurance, while Natural Capital is determined by biomass of fish stocks, area of sea bed leased or accessed by licence, land owned, crops cultivated and other natural resources. Human Capital includes the fishers 'capabilities' including their health, labour, education, knowledge and skills and Social Capital is related to the kinship networks, associations, membership organisations and peer-group networks that can assist the fishers with information, technology transfers and support that facilitate opportunities for them to advance their living standards (Allison and Horemans, 2006; Sherbinan et al., 2007).

\section{Case Study Site}

Papela village, the case study site, is a multi-ethnic group community in the Sub-district of East Rote located on the north-eastern end of Rote Island. The catalyst and importance of this research is evident by a newspaper story in May, 2017, which reports that there are at least 200 cases of illegal fishing per year conducted by traditional fishermen from Rote Island, especially from the village of Papela and that there are about 210 of Indonesian fishermen held in Australia Detention Centres (Victory News, 2017). These traditional fishermen are carrying on their fishing activities not only in the Indonesian Exclusive Economic Zone (EEZ), but also in the Australian EEZ, especially in the waters around Ashmore Reef, or PulauPasir (Sand Island) as it is known by the Indonesian fishermen. These fishing practices are not driven merely by economic factors, but also by their socio-historical background (Nolan and Vincent, 2010) and other multi-dimensional issues (Fox and Sen, 2002; Sembiring et al., 2012). This village was selected also based on the fact that for more than $80 \%$ of households, fishing and other marine resource centred activities are their main livelihood (Benu et al., 2017b).

Legend: H: Human; N: Natural; F: Financial; P: Physical; S: Social.... Capital

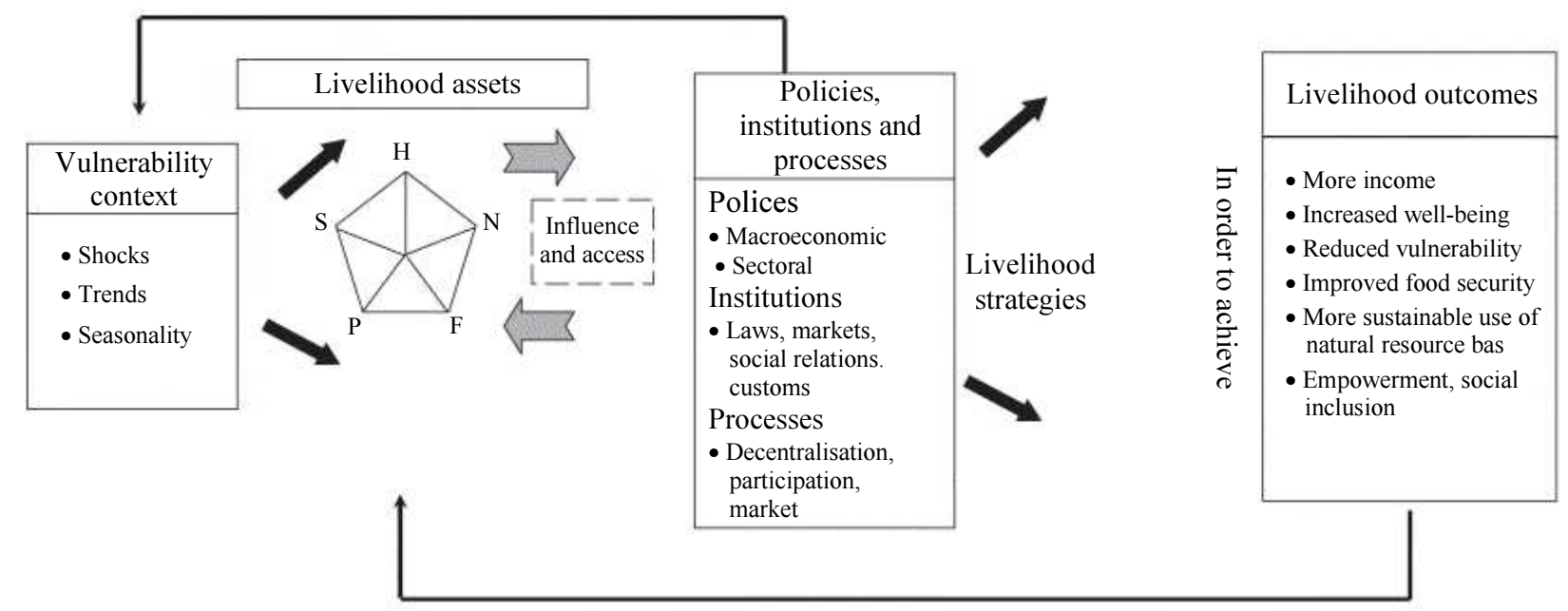

Fig. 3: Sustainable Livelihood Approach (SLA) Framework; Source: Allison and Horemmans, 2006 


\section{Data Collection}

Primary data collection involved formal interviews with key informants including community leaders, religious leaders, traditional leaders and district and village government officials. Focus Discussion Groups (FDG) and interviews were also conducted with members of the community, such as fishermen, their wives and family and village youth. Data was also collected by way of a household survey using a simple random sampling technique of $10 \%$ of households that either have regular fishing activities or seaweed cultivation activities as their main form of income. The interviews and FDGs were guided by prepared purposive questions. The primary data that was collected from the local household members was in relation to input and output activities of fishing excursions and seaweed cultivation. This included fish catch data, seaweed cultivation data, number of labours, quantity and quality of tools and equipment, input costs, revenue, cost of production, gross margins, time allocation and number of families and their level of education attained. Government officials also expanded on government policies and programs.

The secondary data that was collected includes information reported in documents published by government and non-government organizations and private sector organizations at the national, provincial and district level. This data includes total fish catch data, seaweed harvest data, number of inhabitants, number of fishermen, amount of gear and equipment for fishing, existing infrastructure, total output of regional economic activities, government policies and budget allocations, available transportation, among other related data.

Salt farm production was analysed using Policy Analysis Matrix (PAM). Pearson et al. (2003) said that PAM was a flexible research tool in that it can be used for project or policy analysis. Quantitative data focusing on data required for the analysis of government policy for salt production using PAMwas collected. This data included the price of all input costs, total revenue, government subsidies and taxes and productivity and profitability that influence the economic viability of salt farming as an alternative livelihood strategy.

\section{Results}

\section{Existing Conditions of Papela Fishermen}

This research found that under the globally accepted indicators of poverty and household economics such as $\$ 2$ per capita income/day (World Bank) or 2100 calories of consumption per capita/day (The Central Bureau of Statistic of Indonesia), it could be deduced that almost $90 \%$ of the households in Papela are poor.

For the Bajo people who live in Tanjung Pasir, a sand spit sub-village of the village of Papela, the survey reveals that their houses are predominantly a temporary stage house with rough wooden floors and wooden walls (Fig. 4). They are living in squalid conditions with poor sanitation. Commonly, two or three families live together in the one house with no bedroom, one emergency bathroom and all children and parents sleeping together in a big open room (Table 1). The survey also found that, for alternative income, they do not have any productive assets such as livestock, land, vehicles and so forth. Moreover, the education data shows that almost $80 \%$ of fishermen are only primary school graduates and less than $1 \%$ are university graduates. The most important education standard to the Bajo people is that their children can read and write. After this point, children are called on to help their parents to earn money for daily living expenses. The boys can work for the Boss (the boat owner) along with their father and friends and the girls assist their mother doing some daily house activities and preparing to get married when they are teenagers.

When we analyse the prevailing conditions, we come to understand that there is little opportunity for an alternative livelihood for the local people living in Papela. The only immediately accessible economic activity for their livelihood is fishing. Allowing the younger generation to have only the same choice of becoming a fisherman or a housemaid and assistant can be equated to promoting them into the same enduring poverty trap as their parents, which is socially not sustainable. However, comments made during interviews and FDGs revealed that the traditional fishermen in Papela are willing to change, or supplement, the pattern of earning their livelihoods from being off-shore and trans boundary fishermen to other activities matching their skills set and limited access to capital.

Table 1: Distribution of population and level of welfare in Papela, 2016

\begin{tabular}{|c|c|c|c|c|c|c|}
\hline \multirow[b]{2}{*}{ Dusun } & \multirow[b]{2}{*}{ Households } & \multirow{2}{*}{$\begin{array}{l}\text { Poor } \\
\text { Households }\end{array}$} & \multirow{2}{*}{$\begin{array}{l}\text { Pre-Welfare } \\
\text { Households }\end{array}$} & \multicolumn{2}{|c|}{ Population } & \multirow[b]{2}{*}{ Total } \\
\hline & & & & Men & Women & \\
\hline Tanjung & 125 & 122 & 3 & 292 & 276 & 568 \\
\hline Tasisu & 138 & 123 & 15 & 249 & 251 & 500 \\
\hline Anlaso & 107 & 85 & 22 & 214 & 204 & 418 \\
\hline Manulalulen & 132 & 119 & 13 & 273 & 276 & 549 \\
\hline Total & 502 & 449 & 53 & 1028 & 1007 & 2035 \\
\hline
\end{tabular}

Source: BPMD, Rote Ndao, 2016 


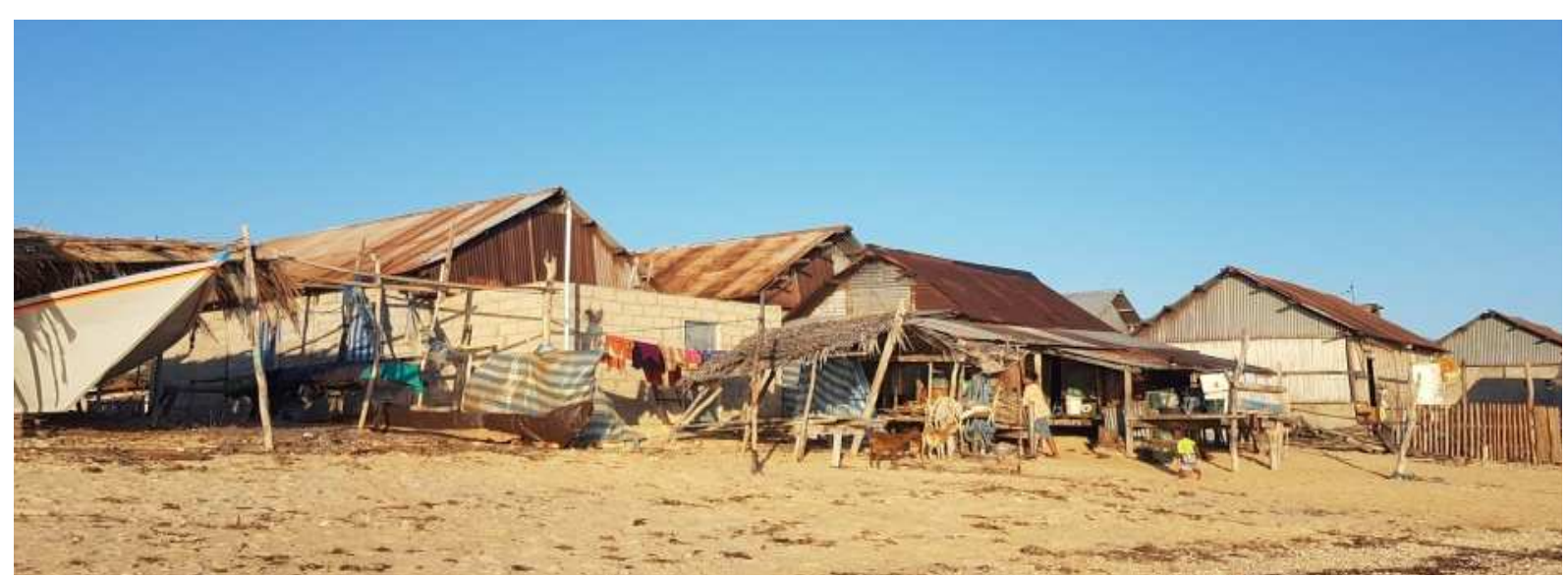

Fig. 4: Living in Poverty, Papela

\section{Previous Alternative Sustainable Livelihood Activities}

The first attempted alternative livelihood programs were seaweed cultivation programs. These programs have been introduced for local people as an alternative livelihood strategy since the $1990 \mathrm{~s}$ by various organisations, such as Indonesian Central, Provincial and Local Government departments, Australian Government departments and foreign aid organisations and NGOs. In 2007, a seaweed cultivation program was introduced by the local government and funded by the Australian Embassy Direct Aid Program, provided the local fishermen with good harvests and enough profit to raise their livelihood and living standards (Ardani, 2017). Based on that experience, the fishermen invested approximately Rp 500000 (US\$ 50) for $180 \mathrm{~m}$ of rope, floats and seed to cultivate seaweed which produces approximately $75 \mathrm{Kg}$ of dry-seaweed, returning a profit of almost Rp 300000 (US\$ 30) or, if they had access to funds for 10 rope lengths, approximately $\mathrm{Rp} 3$ million (US\$ 300) for a month. However, this success story was halted with the Montara oil spill disaster in August 2009, which dramatically affected seaweed production (Ardani, 2017). The Montara oil and gas field is located to the north west of the Australian mainland, $650 \mathrm{~km}$ west of Darwin in the Timor Sea. The Montara oil spill was an oil and gas leak that subsequently left a major oil slick in the Timor Sea that caused an environmental disaster reaching the shores of Indonesian islands facing the Timor Sea (Offshore Technology, 2018).

There are other new alternative economic activities that are being trialled in Papela, such as horticulture cultivation and salt production. However, these projects cannot be adopted by all fishermen because of land requirements and start-up costs. This study found that if new drip-feed irrigation technology could be implemented into horticultural projects, results may show positive returns in large-scale applications, but, for small scale landholders, irrigation projects like this require high investment. Additionally, using this technology actually reduces the labour needed for horticultural activities and therefore does not open new job opportunities for the fishermen or other household members.

The second, new, alternative livelihood is the development of a salt pond business, which also requires a large investment for the appropriate land and equipment. While the Rote-Ndao Regency government is keen to foster a local salt production industry by its inclusion in Regency budget allocations (Haning, 2017), to date, the only salt farming project that has been developed is a small private enterprise (Umar, 2017).

Salt ponds have measureable impacts on the environment, as this type of business needs expansive land clearance, especially of mangrove vegetation in flat tidal zones. However, an in-depth interview with Umar (2017), who was also an illegal fisherman in the 1970s and detained in Australia for 2 months and who started a salt production business in 2006, stated that he made a large initial investment, but now the business can return a profit of more than Rp 50 million (US\$ 5,000) in a year and give a small number of job opportunities for local fishermen.

\section{Analysis of Policy Distortions and Market Failures of Salt Pond Business}

Pearson et al (2003) have said that market failure is one of the causes of divergence. The market is said to have failed when its product is unable to be created or manufactured for a competitive price and does not reflect social opportunity cost that in turn creates allocation of resources as well as efficient product output. There are three types of market failure that cause divergence, namely: (i) Monopoly, that is when sellers control 
market price; or monophony, when buyers control market price; (ii) negative externalities, that is input costs that an involved stakeholder cannot endure the costs incurred; (iii) positive externalities, that is when a share of output benefits cannot be receive by an involved stakeholder. Therefore, a policy is said to be efficient and beneficial for the community if the government is able to create and apply a policy that can eliminate market failure, can put aside inefficient aims and can result in a non-distortive policy.

Divergence of an output cost of an economic activity, or of a commodity, causes obtained private income to differ from social income, thus causing an output transfer (Pearson et al., 2003). Divergence may be positive to cause implicit subsidy or resource transfers which add to system profit. Divergence may be negative too, to cause tax implicitly or resource transfer that reduces system profit.

To measure the value-free output transfer, it is approximated by the ratio of the nominal output protection coefficient. This ratio compares domestic price (private) with social price. If NPCO $>1$, then domestic price is higher than import price (or export price). Thus, the system is accepting protection. If $\mathrm{NPCO}<1$, then domestic price is lower than world price which is not protected. In such situation, there is no policy transfer when the domestic price is equal to the world price. So, NPCO $=1$. Table 2 shows the results of divergence of the business of community salt production in Papela.

\section{Discussion}

Following analysis and consideration of the research data, with regard to alternative sustainable livelihood strategies for village fishermen, results point to a salt pond business as a best-fit alternative income for fishermen. These businesses require large initial investment in infrastructure, land and operational expenses, along with strong commitment from the fishermen and substantial government intervention.

This proposal is based on several factors:

a) Regarding social benefits to the community; salt pond businesses require more employees than horticulture cultivation activities using drip-feed irrigation. Hence, they give more job opportunities for the fishermen. Research data shows that a one hectare salt pond requires more than 10 employees, while horticulture cultivation with drip irrigation needs only 2 labourers

b) Papela still has plenty of available land, which technically is more suitable for a salt pond business than horticultural activities. However, this would need District government assistance for the fishermen to have access to adequate sized plots of flat land close to tidal zone

c) From a socio-historical perspective, the fishermen are more willing to be involved with maritime-based activities, such as seaweed cultivation and a salt pond business than land based horticultural activities

This is evidenced by the successful uptake of seaweed cultivation before the Montara oil spill disaster and Pak Umar's profitable experience with a salt pond business. Additionally, the national demand for salt is high with the biggest consumption by industry causing scarcity of salt supply. This scarcity of salt is currently overcome by a government policy of importing salt in large quantities from a number of exporting countries. However, government policy should be refocused to capitalise on small business and employment opportunities in small, remote fishing villages.

Detailed results of salt pond production analysis, based on data received from Umar (2017), as presented in Table 2, show that the Output Transfer (OT) value obtained is negative. The negative value can be interpreted as the consumer pays while the producer receives cheaper output price than the normal price. In other words, the producer of the community's salt in Papela Village indirectly gives incentive to consumers. The NPCO value of the production of the community's salt in Papela Village is as much as 0.9435 . This value shows that when the actual output price of salt production is Rp $1000 / \mathrm{kg}$ (US\$ 0.10), the salt farmer only receives on average $4.6 \%$ less than the normal price which is Rp1 049/kg (US\$ 0.1049).

The results of the analysis of the IT value of community's salt production in Papela Village, shows the amount of IT value of Rp 1480 472/year (US\$148). The positive value of IT implies implicitly that the salt farmer is taxed due to the existing policy of IT value. The NPCI value of the community's salt production has a value greater than one, which can implicitly explain that the tradable input price at the domestic price level ranges from $0.01 \%(1.1049 / 100)$ to the social price, i.e., more expensive than the social price. Based on the description of the result, it seems that there is relatively little protection for the tradable input producer.

The results of FT value analysis of the community's salt production in Papela Village show a positive value of Rp 1378 114/year (US\$ 138). The positive FT value means that the salt farmer is paying implicit tax due to existing policies or transfers to domestic factor producers. The Labour factor is a major domestic determinant factor in the production of the community's salt, being as much as $37.97 \%$ of the total cost of production and depending on the number of labourers involved. 
Table 2: Results of Divergence Analysis of the Business of Community Salt Production in Papela, 2017

\begin{tabular}{llll}
\hline No & Description & Unit & Value \\
\hline 1. & Output Divergence: & $(1462857)$ \\
& Output Transfer (OT) & US\$/year & 0.9435 \\
2. & Co-efficiency of Nominal Output Protection (NPCO) & Ratio & 148 \\
& Tradable Input Divergence: & US\$year & 1.1049 \\
Input Transfer (IT) & Ratio & 1378114 \\
Co-efficiency of Nominal Input Protection (NPCI) & Domestic Factor Divergence: & US\$/year & $(4321444)$ \\
4. & Factor Transfer (FT) & & 0.1825 \\
& Input and Output Divergence: & US\$/year & 0.8303 \\
& Policy of Net Transfer (NT) & Ratio & $(0.1374)$ \\
\hline
\end{tabular}

Source: Primary Data, 2017 (processed)

The NT value of the community's salt production is negative. The negative NT value in essence shows that the salt farmer profit is more in deficit, implicitly due to market failure of input and output factors. The scale of NT value indicates that the salt farmer in Papela Village receives an actual profit lower than the social profit of the NT value that is Rp. $4321444 /$ year (US\$ 432). The value of PC on the community's salt production is smaller than one. This means that private profit received by the salt farmer is still lower than the social benefit at the proportion which is equal to the $\mathrm{PC}$ value.

The average Effective Protective Coefficient (EPC) is 0.8303 which means that the added value of output at the private price of the community's salt production is $83 \%$ of the added value at the point of complete competitiveness.

The Subsidy Ratio Producer indicator (SRP) of the community's salt production shows a negative value of 0.1374 on average. The scale of the SRP value gives an understanding of the distortive policy of the government on average and/or market failure, resulting in the profit of the salt farmer being reduced by approximately $13.74 \%$ of the economic revenue. The most dominant factor faced in the field of business or in the market is that the sale price is still lower that the social price.

The NPCI ratio shows how much the domestic price (private price) of tradable input differs from the efficient price (social price). If the NPCI $>1$, it means that the tradable input domestic price is more expensive than the input price at the level of world price. It also means that the system seems to be subsidized by existing policies. If the NPCI $=1$, it means there is no transfer and the price of domestic input does not differ from the world input price. The NPCI value being greater that one and the NPCO value being smaller than one, strengthens the notion that government policy is relatively less protective to the community's salt enterprise. Consequently, the added value obtained from the use of tradable inputs is still lower at the level of cost price compared to the social benefit or social price. This shows that the government has not been able to formulate policy incentive for the development of the community's salt production in Papela Village in particular and East Nusa Tenggara (NTT) in general.

Another external condition that determines the actual price received by the salt farmer is closely related to the fluctuating trend of the Indonesian Rupiah exchange rate as a depreciated exchange rate of the Rupiah directly affects the price and competitiveness of the community's salt. As the import of salt continues, the price of domestic salt must compete with the imported product in order to grab a share of the market.

The environmental issues connected with salt production and the technology and technical aspects of salt production also need to be studied further, however, these aspects are not covered in this research.

\section{Conclusion}

The specific aims of the research were, (i) to identify and explain some of socio-cultural factors determining the local people's livelihoods; (ii) based on the sociocultural assessment and economic calculations, suggest an alternative livelihood with comparative advantages for the Papela fishermen as a source of complementary income using their existing skills; and (iii) to analyse government policy for enhancing alternative livelihoods for the local people.

These conclusions can be drawn from the research:

- Since the beginning of the 17 th century up until now, the traditional fishermen of Rote have made regular offshore fishing trips to Ashmore Reef in the south of the Timor Sea. This is attested by the Agreement between the Indonesian and Australian Governments signed first in 1974 and revised in 1989 
- Reflecting on the socio-economic and human factors determining the livelihood of traditional fishermen in Rote, allowing the young generation to have only the choice of becoming a fisherman or household help is the same as promoting them in the same enduring poverty trap as their parents. Attaining a higher level of education than their parents is important for the younger generation to provide them with enough knowledge and skills to confidently look for and embrace alternative livelihood strategies

- The business of community salt production by the people in Rote is an efficient business that has competitiveness from a social aspect as a higher number of labourers are required and from the economic aspect, because of a high demand to increase national salt production. Community salt production also has competitive and comparative advantages and can be used as an alternative source to overcome the scarcity of salt production and to fulfil domestic demand. Further study is needed concerning the environmental safety aspects of salt production and the technology used

- The results of policy analysis shows that the government's will to support the salt farmer seems to be still weak, indicated by the lower value of output received, while at the same time the producer has to pay more expensive input price. Anticipated local government policy to increase the development of community salt production is expected to be a suitable alternative livelihood activity that will help reduce dependence of local labour on fishing activities that carry risks and restrictions, especially in the trans boundary waters between Indonesia and Australia

\section{Acknowledgement}

We would like to thank the Nusa Cendana University, Kupang Indonesia, which has fully supported this work under the research grant Penelitian Pimpinanin 2017.

We would also like to show our gratitude to the Local Government of Rote Ndao, Village Government and fishing community in Papela for their cooperation as a group of respondents to describe the existing conditions for Papela fishermen.

\section{Authors Contributions}

Fred Benu: Coordinated the data-analysis and coordinated among all authors.

Paul G. King: Participated in all activity research and contributed to the writing of the manuscript.

AgusNalle: Participated in all activity research, designed the research plan and organized the study.

Moni Muskanan: Participated in all activity research and write the literature review of the manuscript.

\section{Ethics}

The authors whose names are listed certify that they have no affiliation with or involment in any organization or entity with any financial interest (such as honoraria; educational grants; participation in speak's bureaus; membership, employment, consultanicies, stock ownership, or other equity interest; and expect testimony or patent-licensing arrangements), or non-financial interest (such as personal or professional relationships, affiliations, knowledge or beliefs) in the subject matter or materials discussed in the manuscript.

\section{References}

Adhuri, D.S., 2012. Traditional and 'modern' trepang fisheries on the border of the indonesian and australian fishing zones. Australian National University, Canberra.

Agreement between Australia and Indonesia concerning Certain Boundaries between Papua New Guinea and Indonesia. Australian Treaty Series No. 26. Jakarta.

Allison, E.H. and B. Horemans, 2006. Putting the principles of the Sustainable Livelihoods Approach into fisheries development policy and practice. Marine Policy, 30: 757-766.

Allison, E.H. and F. Ellis, 2001. The livelihoods approach and management of small-scale fisheries. J. Marine Policy, 25: 377-388.

DOI: $10.1016 / \mathrm{S} 0308-597 \mathrm{X}(01) 00023-9$

AMMBOIAF, 1989. Agreed minutes of meeting between officials of Indonesia and Australia on Fisheries, Jakarta.

Anderson, A.R. and B.A. Obeng, 2017. Enterpriseas socially situated in a rural poor fishing community. J. Rural Stud., 49: 23-31.

DOI: $10.1016 /$ j.jrurstud.2016.11.015

Ardani, S., 2017. Papela fishing hostory..

Balint, R., 2005. Troubled Waters: Borders, boundaries and possession in the Timor Sea. 1st Edn., Allen and Unwin, Crows Nest, ISBN-10: 1741152046, pp: 204.

Barlow, C. and Gondowarsito, 2007. Socio-economic conditions and poverty alleviation in Nusa Tenggara Timur.

Bebbington, A.J., 1999. Capitals and capabilities: A framework for analyzing peasant viability, rural livelihoods and poverty. World Dev., 27: 2021-2044. DOI: 10.1016/S0305-750X(99)00104-7

Bene, C., 2003. When fishery rhymes with poverty: A first step beyond the old paradigm on poverty in small-scale fisheries. CEMARE, University of Portsmouth, Elsevier Science Ltd. UK.

Béné, C., 2006. When fishery rhymes with poverty: A first step beyond the old paradigm on poverty in small-scale fisheries. World Dev., 31: 949-975. DOI: $10.1016 / \mathrm{S} 0305-750 \mathrm{X}(03) 00045-7$ 
Bene, C., 2009. Are fishers poor and vulnerable? Assessing economic vulnerability in small-scale fishing communities. J. Dev. Stud., 45: 911-933. DOI: $10.1080 / 00220380902807395$

Benu, F., P.G. King, A. Nalle and M. Muskanan, 2017a. The economic livelihoods of traditional fishermen in rote island in relation to the activities of illegal fishing in transboundary water of Indonesia and Australia. Research Report, Nusa Cendana University, Kupang.

Benu, F., W. Mudita and M. Muskanan, 2017b. A small drop of hope for the dry ground: Introducing drip irrigation to rote island, Indonesia, to convince fishermen to farm during the dry season for an alternative livelihood.

BPMD, Rote Ndao, 2016. Laporan Potensi Desa. Laporan Tahunan, BPMD Rote Ndao, Rote.

BPS Kabupaten Rote-Ndao, 2017. Kecamatan rote timor dalam angka 2016. BPS Kabupaten Rote-Ndao.

Campbell, B. and B. Wilson, 1993. The politics of exclusion: Indonesian fishing in the Australian fishing zone. Indian Ocean Centre for Peace Studies, Singapore.

Carnegie, M., 2008. Development prospects in Eastern Indonesia: Learning from Oelua's diverse economy. Asia Pacific Viewpoint, 29: 354-369. DOI: $10.1111 / \mathrm{j} .1467-8373.2008 .00383 . x$

Carnegie, M., 2010. Living with difference in rural Indonesia: What can be learned from national and regional agendas? J. Southeast Asian Stud., 41: 449-481.

Carney, D., 1998. Implementing the sustainable rural livelihoods approach. Overseas Development Institute UK, London.

Christy Jr., F.T., 1986. Special Characteristics and Problems of Small-Scale Fisheries Management in Developing Countries. In: Natural Resource Economics and Policy, Applications, Miles, E., R. Pealy and R. Stokes (Eds.), University of Washington Press, Seattle, pp: 118-51.

Clark, M. and S.K. May, 2013. Macassan historyand heritage: Journeys, encounters and influences canberra. ANU E Press, Australia.

Forbes, V.L., 1995. The Maritime Boundaries of the Indian Ocean Region. 1st Edn., Singapore University Press, Singapore, ISBN-10: 9971691892, pp: 267.

Fox, J.J., D.S. Adhuri, T. Therik and M. Carnegie, 2009. Searching for Livelihood: The Dilemma of SmallBoat Fishermen in Eastern Indonesia. In: Working with Nature Against Poverty, Resosudarmo, B.P. and F. Jotzo (Eds.), ISEAS Publishing, Singapore.

Fox, J., 1977. Harvest of the palm: Ecological change in eastern Indonesia. Harvard University Press, London.
Fox, J.J. and S. Sen, 2002. A study of socio-economic issues facing traditional Indonesian fishers who access the MOU Box. Environment Australia, Canberra, Australia.

Fox, J.J., 2002. A study of socio-economic issues facing traditional Indonesian fishers who access to MOU box. Research School of Pacific and Asian Studies The Australian National University.

Ganter, R., 2008. Muslim Australians: The deep histories of contact. J. Australian Stud., 32: 481-492.

Gordon, A., 2005. Oceanography of the Indonesian Seas. Oceanography, 18: 14-27. DOI: $10.5670 /$ oceanog.2005.01

Haning, L., 2017. Head of rote-ndao regency formal interview.

Hopwood, B., M. Mellor and G. O'Brien. 2005. Sustainable development: Mapping different. J. Sustainable Dev. DOI: 10.1002/sd.244

Horner, N., 2013. What Is Social Work? 4th Edn., Sage Publishing, London.

Knudsen, M., 2016. Poverty and beyond: Small-scale fishing in overexploited marine environments. Human Ecol. DOI: 10.1007/s10745-016-9824-y

Macknight, C.C., 1976. The voyage to marege': Macassan Trepangers in Northern Australia. Melbourne University Press, Carlton, Australia, pp: 175.

Meier, G.M., 1976. Leading Issues in Economic Development. 3rd Edn., Oxford University Press, New York, pp: 8.

Miletzki, J. and N. Broten, 2017. An analysis of amartya sen's development as freedom. The Macat Libruay, London.

Nolan, B. and P. Vincent, 2010. Ekonomi politik Masyarakat nelayan skala kecil: Sebuah studi perbandingan masyarakat pendatang di rote ndao dan jawa timur. ACICIS Research Report. Malang, Universitas Muhammadiyah.

Offshore Technology, 2018. Montara oil field, Timor Sea. Offshore Technology.

Pearson, S.R., C. Gotsch and S. Bahri, 2003. Aplikasi Policy Analysis Matrix pada Pertanian Indonesia. 1st Edn., Yayasan Obor, Jakarta.

Pellu, L.H., 2008. A domain united, a domain divided, an ethnographic study of social relations and social change among the people of Landu, East Rote, Eastern Indonesia. Thesis, The Australian National University.

Prescott, J., J. Riwu, D.J. Steenbergen and N. Stacey, 2015. Governance and governability: The Smallscale purse seine fishery in Pulau rote, Eastern Indonesia. Proceedings of the Interactive Governance for Small-Scale Fisheries, (GSSF'15), Springer, Cham, Europe, pp: 61-84. 
Purcell, S.W. and R.S. Pomeroy, 2015. Driving smallscale fisheries in developing countries. Frontiers Marine Sci., 2: 44-44.

DOI: $10.3389 /$ fmars.2015.00044

Reardon, T. and S.A. Vosti, 1995. Links between rural poverty and the environment in developing countries: Asset categories and investment poverty. World Dev., 23: 1495-1506. DOI: $10.1016 / 0305-750 \mathrm{X}(95) 00061-\mathrm{G}$

Scoones, I., 1998. Ustainable Rural Livelihoods: A Framework for Analysis IDS Working Paper 72.

Sembiring, P., T. Adiwijaya, D. Rezamudra, J. Haning and M. Bria, 2012. Analis manajemen rantai pasok (Studi Kasus Nelayan MoU Box 1974). Research Report, Balitbang Kementerian Pertahanan, Jakarta.

Sen, Amartya. 1999. Development as Freedom. New York: Anchor Books. Chicago.

Sherbinan, A., Leah K.V. Wey, K. McSweeney, R. Aggarwal and A. Barbieri et al., 2007. Rural household demographics, livelihoods and the environment. Global Environ. Change, 18: 38-53. DOI: 10.1016/j.gloenvcha.2007.05.005
Stacey, N., 2007. Boats to Burn: Bajo Fishing Activity in the Australian Fishing Zone. 1st Edn., ANU E Press, Canberra, ISBN-10: 1920942955, pp: 222.

Therik, W., 2008. Nelayan dalam bayang Juragan: Potret kehidupan nelayan tradisional bajo di tanjung pasir, pulau rote, nusa tenggara timur. Working Paper Institute of Indonesia Tenggara Studies, Universitas Satya Wacana, Salatiga.

Umar, 2017. Salt farm production.

Victory News, 2017. Australia tangkap nelayan NTT. Victory News Kupang.

Weeratunge, N., C. Béné, R. Siriwardane, A. Charles and D. Johnson et al., 2015. Small-scale fisheries through the wellbeing lens. J. Fish Fisheries, 15: 255-279. DOI: 10.1111/faf.12016 